\title{
Estilizaciones de un tema metafísico en Alfonso Reyes
}

T A obra ensayistica de Alfonso Reyes es tan vasta en sus múltiples 1 formas y variadísima temática, que no intentaremos reseñaria toda en estos breves momentos sino limitarnos a un pequeño grupo de ensayos dentro de otro más grande - los de tema metafísico- no para enjuiciar sus ideas filosóficas (de eso no somos capaces), sino sobre todo para examinar algunos de los medios artísticos que emplea Reyes para estilizarlas en forma literaria. No pensamos en Reyes como un filósofo sistemático, sino como poeta que dentro de su preocupación humanística muy amplia da expresión poética en prosa a un quehacer metafísico.

La temática metafísica abunda en los ensayos de Alfonso Reyes, intensificándose especialmente en los volúmenes Ancorajes (I95I), Mar. ginalia (dos series: 1952, 1954) y Las burlas veras (dos series: 1957 , I959). Aquí nos concentraremos en un grupo de cinco ensayos de la serie Ancorajes, que tratan todos de variaciones de un tema metafísico central, y que fueron elaborados en diversas fechas: "La caída", I928; "La catástrofe", I937; "Palinodia del polvo", 1940; "Meditación sobre Mallarmé", 1942; "Metafísica de la máscara", 1945. Debido a las limitaciones del tiempo-espacio, tendremos lamentablemente que saltar sobre muchos detalles interesantes y ricas implicaciones adicionales.

El tema común de este grupo de ensayos-desarrollado con distin. tas variaciones- es el de "la caída" o del derrumbe cósmico. Aquí nos parece que desde muy temprano Reyes se asoma a las angustias metafisicas de nuestro tiempo, con raices en el intuicionismo bergsoniano de su generación y luego afinidades - avant la lettre-con el cuasi-existencia. lismo de un Albert Camus y con la preocupación por los enigmas del espacio-tiempo de un Jorge Luis Borges. Todo esto en un gran humanista conocido por su serenidad clásica. 
El ensayo titulado La caida - exégesis en marfil formula una teoria del universo en términos de derrumbe, de pereza cósmica, de caída de la materia equivalente en lo teológico a la caída de Luzbel. ${ }^{1}$ Literariamente, lo que nos parece más interesante es la manera alfonsina de presentarla a través de un estímulo artístico, ${ }^{2}$ el de un objeto de arte-escultura en marfil一 visto en el Museo Arqueológico de Madrid, con su carácter plástico-visual, que se refuerza por el agente catalítico de la memoria que pre. cipita la reacción.

Después de una meditación nutrida de nuevas contemplaciones del objeto que producen nuevas imágenes - el demonio opuesto al santo y al aeróstato, la masa celeste hecha acrolito, asimilación asociativa a una pintura del Greco- volvemos al punto de partida para sacar una nueva implicación:

(Visto el objeto a contraluz, entre las venas caladas del marfil, entre la parrilla satánica, otro, otro labrado indefinible -el la. brado del aire-me daba la pauta del trasmundo, del trasmundo virgen aún para los sentidos $\mathrm{y}$-debo decirlo- prometedor).

Este enfocarse en el elemento del aire a través del marfil crea un nuevo símbolo del "envés de la tela" o "reverso de la medalla" que invierte la perspectiva de negativa en afirmativa, abriendo un hotizonte de infinidad para futuras meditaciones, como la titulada Meditación sobre Mallarmé. Estructuralmente, este volver al punto de partida y luego apun. tar hacia el infinito anticipa la forma espiral que se verá en la Metafísica de la máscara.

La catástrofe, ensayo minimo en su brevedad, enfoca el mismo concepto del derrumbe cósmico mediante una sola imagen dinámica, de carăcter primordialmente cinético, relacionado con las leyes de la física, la imagen de la honda:

Cuando la piedra de la honda viene en camino, algo que es mineral en nuestra carne la presiente por imantación...

Hay un derrumbe cósmico en marcha constante hacia nusotros. Tardará milenios en llegar, o tardará sólo unos segundos. Pero el corazón, siempre profético, adivina que el tiempo, el espacio y la

1 Luis Leal ha comentado en tal sentido este ensayo, en "La caída de Alfonso Reyes", El rebilete, México, No. 4 (febrero 1962), PP. 5-8.

2 "El propio Reyes comenta este tipo de estímulo en "Los estimulos literatios" (tipo visual), Tres putntos de exegética literaria, en Obras completas, XIV, México: Fondo de Cultura Económica, 1962, pp. 275-280. 
causa son endebles, y que una amenaza, llena de explosiones de astros está suspendida, zumbando, sobre nusstras frentes.

Palinodia del polvo enfoca el concepto del derrumbe cósmico a través de otro estímulo y otro símbolo: el estímulo visual y táctil del paisaje y el símbolo táctil y meteorológico del polvo. Ya vimos cómo en La caida el aire fue símbolo de promesa. En la Visión de Anábuac de Alfonso Reyes, el sentido espiritual del valle mexicano se sintetiza en el concepto atmosférico "la región más transparente del aire", en que el aire tam. bién es símbolo de promesa, de claridad, inspiración y renovación del espíritu. Este ensayo presenta la negación de ese símbolo metafísico:

¿Es ésta la región más transparente del aire? ¿Qué habéis hecho de mi alto valle metafísico? ¿Por qué se empaña, por qué se amarillece? Corren sobre él como fuegos fatuos los remolinillos de tierra. Caen sobre él los mantos de sepia, que roban profundidad al paisaje y precipitan en un solo plano espectral lejanías y cercanias, dando a sus rasgos y colores la irrealidad de una calcomanía grotesca, de una estampa vieja artificial, de una hoja prematuramente marchita.

Mordemos con asco las arenillas. $Y$ el polvo se agarra en la garganta, nos tapa la respiración con las manos. Quiere asfixiarnos y quiere estrangularnos.

Asi el valle de Anáhuac, antiguamente tan limpio y tan despejado, hoy día está asediado de tolvaneras y se cubre de polvo. Con el paso del tiempo, el mundo ha evolucionado en la dirección del derrumbe, y este polvo se vuelve símbolo del derrumbe y desintegración de todas las cosas, que acaban por volver al polvo, a la nada:

Microscopia de las cosas, camino de la nada, aniquilamiento sin gloria; desmoronamiento de inercias, 'entropía'; venganza y venganza del polvo, lo más bajo del mundo.

El ambiente de pesadilla futurista amenazadora culmina al final en esta apoteosis del polvo:

¿Será que el polvo pretende, además, ser espíritu? ¿Y si fuera el verdadero dios?":

En su Meditación sobre Mallarmé Reyes ahonda en la angustia me. 
tafísica a través de la creaciôn literaria, sentida en las luchas del poeta Mallarmé con "la tortura técnica". Donde en su estudio inicial de Mallarmés Reyes encontraba al mundo de la caída, del derrumbe cósmico: "la desesperación ante esta irremediable caída desde la cima de la realidad hasta el fondo de la página escrita", ahora ha descubierto una nueva perspectiva en que la caída al abismo podrá llevar a una nueva subida:

Pensemos, ahora, que el derrumbe desde la cima de la realidad hasta la página muda ... no sea necesariamente una angustia, sino un grávido y acelerado placer, por cuanto encierra en sí el propio dibujo de una esperanza, el sentimiento de una ascención ulterior, de un rebote hacia arriba $\mathrm{y}$, lo que es mejor, hacia más arriba que antes. Así el cirquero que se vale del trampolín para poder saltar más alto. O el nadador, cuya zambullida respira ya la victoria de un delicioso setorno a la superficie, donde el bien perdido del aire recobre un valor de creación reciente y anhelada. El ángulo de incidencia hacia abajo, lleva ya; en preñez geométrica, el ángulo de reflexión hacia arriba.

Reyes encuentra su propia salvación del abismo metafísico en la exuberancia de la creación poética que hace nuevas conquistas y descubre nuevos mundos, saltando como resorte desde el fondo de la sima hasta las cimas o cumbres - a la vista de otros horizontes. El aire nuevamente es símbolo de promesa, esperanza, exuberancia tefrescante y renovación del espíritu. La oposición de caida y subida que forma el eje de este ensayo se cristaliza en una brillante cadena de imágenes: primero el núcleo de tres imágenes complementarias -el cirquero, el nadador, los ángulos de incidencia y reflexión: dos imágenes deportivas, una imagen geométrica. Una nueva elaboración de la imagen del nadador lleva a una constelación final de tres imágenes-el escarabajo egipcio que "trabaja con los residuos de una catástrofe vital" y produce nueva creación; y el doble símbolo de Mallarmé y los dados, y de las boleadoras de gaucho: es decir, desafio al azar, y la aventura de la cacería suprema.

Metafísica de la máscara: En este ensayo Reyes vuelve al tema de la caída o del derrumbe metafísico en la dimensión enteramente negativa, a través de otro estímulo artístico: el de una colección de antiguas máscaras mexicanas. La contemplación de las máscaras pone en marcha toda una serie de divagaciones sobre diversos temas o subtemas creando una

3 "Sobre el procedimiento ideológico de Stéphane Mallarme"., 1909, Cuestiones estéticas, en Obras completas, I, Mexico, 1955, pp. 89-101. 
estructura espiral en que el pensamiento vuelve varias veces al estímulo original para partir nuevamente a desarrollar otro tema marginal y final. mente trazar la visión cósmica de la Caída que apunta hacia el infinito, pero sin la sugerencia prometedora que encontramos en La caida, más prominente aún en la Meditación sobre Mallatmé. Un rasgo peculiar de estas máscaras indigenas -que representan una cara dentro de otra cara, formando una serie infinita-lleva a esta reflexión final:

Pero he aquí que este universo en series, en dimensión de multiplicaciones hacia adentro (la máscara de la máscara de la máscara, los ojos de los ojos de los ojos), nos produce una impresión de vér. tigo: tonel de las Danaides, pesadilla sin palpable fondo. Por aquí llegamos a sospechar que la existencia puede ser (casi) un mero amontonamiento de la nada, cuyas leves coagulaciones se van espesando al encimarse $y$ acaban por darnos el engaño de una sustancia verdadera, en la que nuestros sentidos se detienen y que nuestra mente cree asir con esas sus garras invisibles. Anda por ahí cierta metafísica para la cual el ser es, también, un espesarse del no ser, visto en perspectiva. El tiempo real de Bergson es, para esta meta. física, algo como el sabor de la nada, remansado en los cimientos de nuestra conciencia. ¿Hasta dónde caló el mascarero indígena, en esta vertiginosa caída rumbo al centro del universo? Detengámonos: Mallarmé temía precipitarse con sus dos alas desplumadas, "por miedo de caer durante toda la eternidad'. ¿No es esto lo que aconteció a Satanás, Señor de la Caída?

Volviendo a Mallarmé - su protagonista de la creación poética- y a la imagen teológica de Satanás - presentada en el ensayo La caida-Reyes a través de esta imagen de las máscaras viene a acentuar la existencia como amontonamiento de la nada (concepto antes visible en la Palinodia del polvo) y del ser como espesarse del no ser - visión que nos parece ya cercana de la de los existencialistas y cuasi-existencialistas de la postguerra mundial No. 2, especialmente Albert Camus cuya última novela se titula La caída ("La Chute") y cuya imagen mitológica de Sísifo ( $E l$ mito de Sísifo), condenado a subir repetidamente una piedra desde la base de una montaña a su cumbre, no deja de tener alguna afinidad con la alfonsina de las Danaides, condenadas a seguir llenando de agua un tonel sin fondo. 
Asi, en este pequeño grupo de ensayos hemos visto un ciclo de ideas. metafísicas desarrolladas en cinco variantes, con distintas maneras de proyección artística - modelos ensayísticos del excelso pensador-poeta del ensayo que es Alfonso Reyes.

JAMES WILLIS ROBB.

George Wasbington University 